\title{
An Analysis to the Hierarchy of Financial Debt: Based on the Pyramid of Financial Liabilities
}

\author{
Saisai-zhang \\ International Business School, Shaanxi Normal University \\ Xi'an 710119, Shaanxi \\ Email: zhangsaisai@snnu.edu.cn
}

\begin{abstract}
In recent years, with the endless appearance of various financial innovations in our country, the bubble of monetary assets has become seriously and the risk exists in nonbank financial institution has become a hot area of research. While the existing research focuses on the different types of risks, and the debt risks created by different financial institutions are rarely involved. According to these conditions, this paper studied the different views of Post-Keynesian about banks and other financial institutions based on the pyramid of financial liabilities, and to analyze the hierarchies of financial debts created by different bodies, especially banks and non-bank, in the pyramid of financial liabilities, and to provide some targeted policy comments for strengthening the regulation of different financial debt risk in China.
\end{abstract}

Keywords-The hierarchy of money; The pyramid of financial liabilities; Non-bank financial institutions; "Fictitious" liquidity

\section{INTRODUCTION}

"Hold the bottom line of systemic financial risk", since that was proposed firstly in the 19th CPC National Congress, preventing the risk of shadow banking and various non-bank financial institutions (NBFIs) and standardizing its development have become the focus financial works. The risks of various financial debts are hotly in academia. While the existing literatures mostly studied from its aspects, such as credit risk, liquidity risk, exchange rate and interest rate risk, and that lack targeted and underlying research on financial debts created by different bodies. There are endless problems of supervision vacuum and regulatory arbitrage under the separated supervision framework of China. Against this backdrop, this paper attempted to analyze the levels of debt created by different entities, based on the pyramid of financial liabilities. In addition, this article abandoned the mainstream view that "Banking is the institution of money creation, while NBFIs is merely a loan intermediary", and specifically distinguished the different levels of liabilities created by banks and NBFIs, and to explore their essential differences. This paper summatively pointed out that like banks, NBFIs can also create liquidity through debt creation, the difference is that NBFIs create unsecured and unstable "fictitious" liquidity, and that can lead to financial crisis easily. This paper hopes to provide recommendations for standardize the development and strengthen the supervision of NBFIs.

\section{THE DEBT NATURE OF MONEY}

Since the outbreak of the financial crisis, the theorists have begun to reflect on whether the mainstream theories and policies can effectively guide economic development. The essence of money is hotly debated once again. The PostKeynesian Economics believes that money originated from the debtor-creditor relationship, and its nature is a kind of debtrelation. This view has been recognized by more and more mainstream scholars.

The mainstream monetary theory thinks that money is the production of the development of barter, experiencing the livestock, tobacco, shells, etc. in the early barter stage, and then the precious metals, modern banknotes and cheque deposits, and even the current virtual currencies [1-2]. However, these arguments are hardly convinced and there are many disputes. First of all, "tally", which embodies creditor's rights and debts appeared in the primitive society more than two thousand years earlier than the earliest coinages [3]. Secondly, The money "fei" ${ }^{2}$ that used more than two thousand years in Yap, overturned the idea of coin reducing transaction costs, because it is needn't to hold bulky "fei" when trading [4]. Whether it's "tally" or "fei", it shows that the mainstream view about the nature of money is flawed. The purpose of holding money is not to facilitate the transaction, but to obtain some "credit" or payment commitments.

With the development of network, paper money gradually withdrew, and the mainstream theories about money are controversial, while the view that money is account symbol is increasingly recognized. Martin believes that the "Fei" indicates that money is not a commodity. Yap's money is not the "fei", but the clearing system that has a set of credit behind, and "fei" is just a token of accounting and clearing [4]. Therefore, the nature of money is a mechanism that consist of credit account and clearing system [5]. As a result, the nonmainstream theory that thinks the nature of money is a kind of "credit" or debt-relation has been developing rapidly, and it is recognized by more and more mainstream scholars. PostKeynesian scholars' the discussion of the nature of money can be traced back Fumu used in original social trading, it reflects the basic function of money is a unit of account. When the transaction occurs, a debt-debtor relationship generate. The debt nature of money is explained as follows:

1The "tally "is a stick that carved out of the groove in some way to indicate the amount of debt owed debtor's name and transaction date are written on both sides of the stick, then the stick is dragged from the middle, divided into two, but they were not completely symmetrical, the longer one hold by creditor is called "stock" and the shorter one hold by debtor is called "stub", When the debt is repaid, the two woods are consolidated so that both the debtor and the debt amount are verified. 
First, money reflects the relationship of debt: During the prevalence of religion in Europe, everyone is born guilty and must pay a certain dues to the church to pay off their debts incurred by their own lives. After the country emerged, the state imposed taxation and required citizens to pay taxes in their own country's money, which is actually government debt, and reflects the relationship between government and citizens. The debt-relation of money is also reflected in the paper. For example, the front of each Dollar bill is marked with "This note is legal tender for all datts, public and private"; the front of each Pound sterling banknote clearly identifies the promise of the Queen of England: "I promise to pay the bearer on Demand the sum of XX pounds." [5] The renminbi is also a kind of debt-relation certificate. Each renminbi with a denomination of RMB 10 is marked with the words “中国人民银行” and “拾元” , indicating that the People's Bank of China has 10 yuan of debt to the public and is obligated to pay off its debts.

Second, the non-mainstream theory that money reflects debt-relation reveals the social nature of money: there must be money units, such as China, which is "yuan". The money issued by state that called state money is originally used by citizens to pay off their debt (tax) of the country, that results in the demand for state money [7]. In the market, the demanders and the surplus can trade, and then the demand for the state money is further expanded. That is" tax-driven theory".

Finally, the sum of the credit and debt of the entire economic system is zero. Minsky believes that money has two aspects of the balance sheet, and any asset expressed in money must be a liability expressed by others. Money represents the relationship of debts. There must be creditors and debtors. The money that only represent one's assets or liabilities does not exist [8]. Therefore, in the entire economic system, the sum of credit and debt must be zero.

In recent years, the virtual currency has attracted more attention. Among them, Bitcoin, which appeared in 2009, is developing most rapidly and has the most extensive impact. That triggered people to think about whether virtual currency is money. Some people think that the emergence of Bitcoin is a huge challenge to the current monetary system, calling it "the future of gold." In fact, from the perspective of the debt nature of money, Bitcoin does not reflect the creditor-debt or relationship granted by the state and it is not money [9].

\section{THE HIERARCHY OF MONEY AND THE PYRAMID OF FINANCIAL LIABILITIES}

The metalmonism argues that the reason why metal money act as a medium of exchange is that their precious metal content makes their value independent of the form of money. However, the quality and quantity of the precious metal cannot be effectively guaranteed, that needs government's stamp and guarantee, before its widespread circulation [11]. Moreover the government's promise or stamp is backed by government credit. It can be seen that the circulation and use of any money is supported by the credit or commitment of the issuer.

Knapp also pointed out that all currencies are "notes." Its effectiveness stems from the fact that the issuer declarations it can be accepted as a form of payment. It is only when accepted

2The "fei" is a kind of boulder, used as medium of exchange in Yap. The biggest feature is that the owner does not need to hold it when trading. No one has ever tried to move the boulde (fees) back home, after the transaction.

3The"true"liquidity refers to the ability to convert to national debt, secured short-term debt, mainly governmental and bank liabilities occupying the first and two layers of the pyramid; and the "fictitious" liquidity is defined as debt exchange not guaranteed by sovereign states, liquidity depends on market liquidity or the issuer's financial status and lacks stability. by other economies, the "notes" become money. In fact, Minsky says" everyone can create money; the problem is to get it accepted". He thinks that there is nothing special or elusive about money. Money represents debt-relation or payment commitment, When one create their debt and the others willing to hold that, money is created privately.[10]The money represents commitments or debts, and anyone can issue their own money by issuing their debt, the key is whether their debt or money can be accepted. Although everyone can create their own money, but it is different, because the acceptable levels and liquidity of the money created by different person is different. Money is hierarchical, and the degree of acceptance and liquidity of their money or debts determines the hierarchy of money. Therefore, the acceptability of the debt issued by different entities is different, these money with different liquidity constitute the monetary hierarchy. The acceptability of the top money is the highest, and the underlying is the lowest, the acceptance level from top to bottom is decreasing.

The level of money in the pyramid depends on the acceptability of social. The state money includes cash and reserve is the most acceptable and at the top of the monetary pyramid; bank money that is bank deposits is the second and, and at the second floor; while corporate and household debits have the lowest acceptable level and the least liquidity, at the bottom of the monetary pyramid. [11] The specific explanation is as follows:

First, taxes determine that the state money is the most acceptable and at the top level of the monetary pyramid. The government announces that its nationals must pay taxes to the government and must use a certain form of money as the means of paying taxes. That increases the demand of this money for taxable, to repay their debts taxes and evade punishment. The certain form of money called state money, thus, taxpayers need state money to pay off their taxes (debts) to the country. But it does not mean that people who without taxes do not need state money. Because taxpayers who need state money will require payment in state money during the day-to-day transactions, people without taxes also need state money to meet their daily trading needs [7]. The state money includes cash and reserves held in the central bank account.

Second, the banks money is inferior to the state money at the second level of the monetary pyramid. Because it's acceptability or liquidity is second only to state money. In fact, the money created by banks not only include demand deposits, but also including the non-deposit money, such as bank check, the liquidity and acceptable of these money are also different, so the levels are different. In fact, non-deposit liabilities are lower than bank deposits. Nonetheless in order to simplify the analysis what we're talking about the banks money, here only refers to the demand deposit. The higher acceptability of bank money stems from its acceptance by the government's payment system. The government stipulates that the bank money, mainly bank deposits, can be used to pay taxes. Actually, the settlement of transactions is mainly the bank money. The bank money and state money are collectively referred as the decisive currency or monetary base. [12]

Finally, the money created by business and family is at the bottom of monetary pyramid, and with the lowest acceptable 
and liquidity. The monetary rating of these money depends on their ability to convert into banks money or state money without price depreciation, or on its liquidity [13]. Businesses and families money can convert into bank money and be accepted ,the secret is that its debt is convertible, at least may exchange for the higher level of money in the pyramid.[11] In fact, different companies issue different levels of money, but this paper generalizes them to a same level for ease of analysis. The money level is shown in figure 1 below.

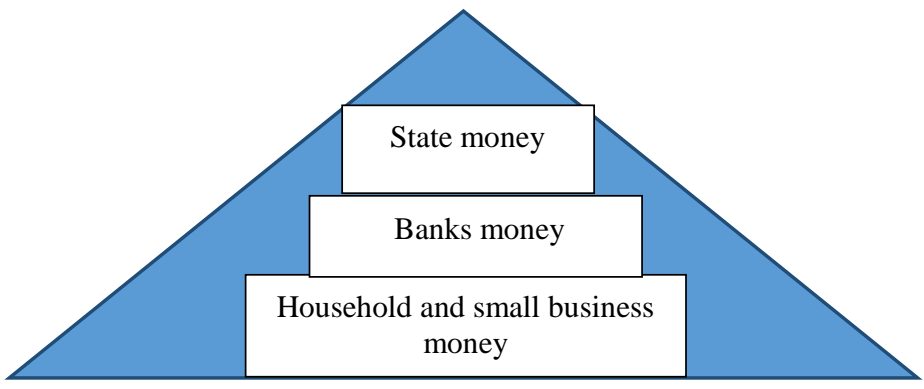

Fig. 1. the Hierarchy of Money

Based on the analysis of the hierarchy of money above, we can explain the pyramid of financial liabilities. Minsky believe in that money represents a debt-relation, it is the asset of one party and must be the liability of others, it is at once an asset and a liability of different person. Minsky suggests treating money as a balance sheet operation, or as a two-sided balance sheet phenomenon. That means money is the liability of the issuer, and also is the asset of the recipient. Specifically, state money is the country's debt, the bank money is the bank's debt, and the corporate and residents money also are their debt.

In the pyramid of financial liabilities, the liabilities levels range from high to low, from top to bottom. As we can see, the state money with the highest credit and most liquid, is the foundation of other credit money and the last means of payment and settlement, so the government liabilities has the highest level, located at the top of the pyramid. The bank liabilities (demand deposits) is second only to government liabilitie. The reasons are that the central bank guarantees demand deposits will trade at par with government money; bank money are accepted in payment of taxes, and it's liquid nearly as state money. Concrete can be explained by the process of loans creation. When the enterprise has the capital requirement to apply for the loan, the assets of the commercial bank will increase, and the customer deposits that is liabilities of bank in its balance sheet also increase the correspondly [14]. Household and small business liabilities' liquidity, convertibility and acceptable are gradually declining, so they are located in the last floor.

\section{THE DEBT LEVEL AND LIQUIDITY CREATION OF NON- BANK FINANCIAL INSTITUTION}

The pyramid of financial liabilities has analysed the debt Level of state, banks and enterprises, but it does not discuss the debt created by NBFIs. Kregel further development and perfect the pyramid of financial liabilities, he distinguished NBFIs with banks, and think that NBFIs liabilities under the level of Banks' liabilities, and above the debt level of non-financial institution in the pyramid [15]. Like banks, NBFIs also can create their own liquidity liabilities by issuing their own money. But unlike banks, the level of their liabilities is different. The acceptability and liquidity of NBFIs liabilities is significantly lower than that of bank liabilities. So the level of NBFIs liabilities is lower than banks demand deposits. There a pyramid of financial liabilities evolved from the money hierarchy, as shown in Figure 2 below. We incorporate NBFIs into the new pyramid of financial liabilities. In the new pyramid, NBFIs' liabilities, such as repurchase agreements of Investment banking is on the third floor. Their levels are between banks and non-financial institutions, that under the level of banks' liabilities, above the level of non-financial institution's liabilities.

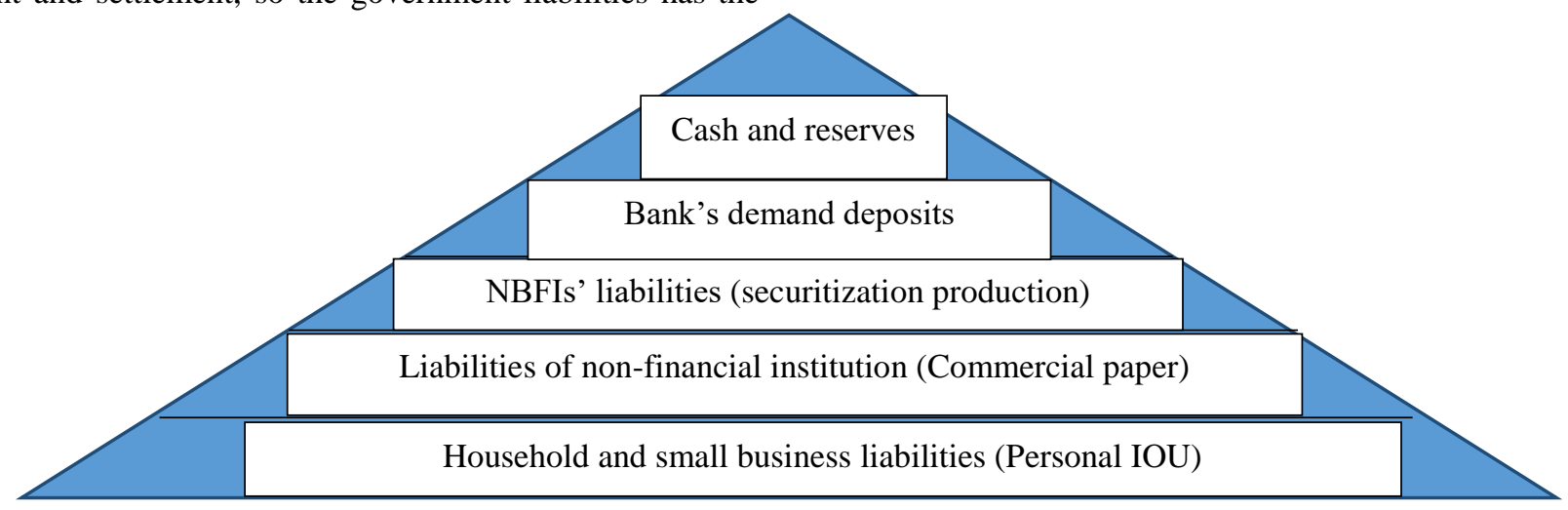

Fig. 2. the pyramid of financial liabilities

For instance, the investment banking can create their own liabilities by selling packaged securities that is some securitization production. The investment bank could buy mortgage-backed securities (MBS) from the subprime mortgage companies, then package and securitize them, and issue it's Collateralized Debt Obligation (CDO) to investors. The investment bank created its own debt that is CDO during the securitization process. The investment bank seller it's liabilities (CDO) in exchange for bank's liabilities, it is clear that the conversion of the CDO into bank's can be widely circulated. And its liquidity is secondary to bank's. Therefore, the level of NBFIs' liabilities is lower than bank's.

Kregel thinks that NBFIs and banks also can create their liabilities while creating liquidity. Banks create liquidity by issuing loans, and non-bank financial institutions can create 
liquidity through asset securitization. The investment bank continue to buy MBS with the financing from selling their debt (CDO). This process expands its balance sheet and creates liquidity. The key is that they create different liquidity. Banks created the "true" liquidity that is secured and convertible into state money, while NBFIs create the "fictitious" liquidity ${ }^{3}$ that is unsecured and unstable. And the creation of the "fictitious" liquidity depends on the liabilities' acceptable level of other economies, especially banks. The proliferation and collapse of "fictitious" liquidity can easily lead to a financial crisis [15]. The "fictitious" liquidity is sensitive to market changes. That is to say, as long as the financial markets in the boom phase, asset prices in a rising period, financial innovation tools such as asset securitization circulated, liquidity dried up won't appear in the market. But, once the financial crisis appear, asset prices will appear downward spiral, credit chain rupture, wealth, further aggravate the liquidity crunch, lead to the entire financial system collapse [16]. Therefore, Therefore, the financial supervision department should strengthen the monitor of "barbaric" growth of NBFIs and the barbarous growth of financial innovation products, thus controlling the arbitrary creation of "fictitious" liquidity, preventing the development of covert financial risks, holding the bottom line of systemic financial risk. That become the workforce of China's financial industry regulatory direction.

\section{CONCLUSION}

Based on minsky's monetary and financial theory, this article focuses on combing and analyzing the perspectives of the debt of money, money hierarchy, the pyramid of financial liabilities, focus on analyzing the different levels of financial debt created by different financial institutions especially NBFIs And then analyse the creation process of "fictitious" liquidity of NBFIs. Conclusions are as follows: First, the nature of money is liabilitie, which reflects debt-relation. Everyone can issue their money, but the money is different and they have different hierarchy. The hierarchy of money depends on the acceptability of the money. Secondly, money that represents debt-relation is the issuer's debt, thus different hierarchy of money determine the level of liabilities created by its issuers. The level is their position in the pyramid of financial liabilities and that depends on the acceptability (or liquidity) of liabilities. Among them, the highest level of government liabilities (taxdriven theory), followed by bank liabilities, and the lowest level of liabilities of non-financial institutions, while liabilities of NBFIs lie between bank and non-financial institutions liabilities. Finally, financial regulatory authorities should strengthen the supervision of NBFIs', prevent the blind expansion of "fictitious" liquidity. While the daily transactions of economic agents generate debts, they are also continuously creating liquidity. The liquidity created by different entities is different. Although NBFIs and banks can all create debt, NBFIs create unsecured "fictitious" liquidity that can easily trigger systemic financial risks. Therefore, the prevention of systemic financial crisis must strengthen regulation of the creation of "fictitious" liquidity created by NBFIs.

\section{REFERENCES}

[1] Say.J.B. "Introduction to Political Economy"[M]. Huaxia Publishing House, 2014.

[2] Samuelson "Economics"[M]. Shanghai University of Finance Press, 2010.

[3] Wray, L. R. "Interpretation of Modern Currency: Realizing Ful Employment and Price Stability" [M].Central Compilation and Translation Press, 2011

[4] Martin Deng Feng. "History of Currency: Money: the unauthorized biography" [M]. CITIC Publishing House, 2015.

[5] Wesson. "Rethinking the Nature of Money" [J]. Research on financial issues, 2016, (10): 17-21

[6] Lili Li, Hongmei Zhang. "Comparison of the View of the Nature of Money based on transactions and debt" [J]. Contemporary Finance, 2014 (10):57-66.

[7] Xinhua Liu, Wen Xian. "The Nature of Money: Mainstream and Nonmainstream Dispute" [J]. Comparison of Economic and Social Systems, 2010, (06): 174-181

[8] Xinhua Liu, Nini Li, Mei Bai. "Post-Keynesian Currency Theory and Its Enlightenment to China" [J].Western Finance, 2010(07):25-26.

[9] Songcheng Sheng, Xuan Zhang. "Virtual currency is not money in essence - take Bitcoin as an example" [J]. China Finance, 2014, (01):35 37.

[10] Wray, L. Randall. 1990. Money and Credit in Capitalist Economies: The Endogenous Money Approach. Aldershot: Edward Elgar

[11] Bell S A. The Hierarchy of Money [J]. Ssrn Electronic Journal, 1998(9805014).

[12] Bell S. The role of the state and the hierarchy of money [J]. Cambridge Journal of Economics, 2001, 25(2).

[13] Nersisyan Y, Dantas F. Rethinking liquidity creation: Banks, shadow banks and the elasticity of finance $[\mathrm{J}]$. Journal of Post Keynesian Economics, 2017(4).

[14] Wen Xian, Xiaoying Feng. "Loans create deposits and the endogenous supply of money -- based on the perspective of monetary nature."'[J] Journal of Guangdong University of Finance, 2012, (01):14-23.

[15] Kregel, J. 2012. Regulating the Financial System in a Minskian Perspective. [J], March 22-23.

[16] Qi Xiao, "A new form of the shadow banking system and liquidity creation." [J]. Financial theory and practice. 2012 (05):17-2 